\title{
Developing Intercultural Competence for Prospective TISOL Teachers through Flipped Learning
}

\author{
Prima Vidya Asteria \\ Universitas Negeri Surabaya \\ Surabaya, Indonesia \\ primaasteria@unesa.ac.id
}

\begin{abstract}
Today, the acquisition of intercultural competence in foreign language education has become a growing interest. This study aims to describe the lesson plan for understanding intercultural competence as TISOL Teachers based on Flipped Learning. This research uses a descriptive qualitative research approach. The subjects of this study were TISOL teaching candidates who took TISOL/BIPA courses in the Indonesian Language and Literature Department of a certain public university in Surabaya. The researcher designed lesson plan based on Flipped Learning (FL). Based on FL, the lecture activities are included before in class, during class, and after class activities so that it can optimize the learning process to achieve lecture competency targets. Lectures are simulated through synchronous and asynchronous activities. The data analysis and processing model uses the principles of data reduction, data presentation, and conclusions and verification. The credibility and validity of research data is evidenced by the triangulation technique. Based on the analysis of the data it can be concluded that the design is in the good category $(80)$ and can improve the intercultural competence as TISOL Teachers. This design is feasible to use, but the research suggests for adding more materials about foreign language teaching.
\end{abstract}

Keywords—competencies; TISOL; BIPA; Prospective Teacher; Flipped Learning

\section{INTRODUCTION}

Students Teaching Indonesia to Speaker of Other Language (TISOL) program are dominated by adults [1]. Therefore, the selection of TISOL material is influenced by three factors. First, adults already have the capital of insight, experience, and knowledge in learning languages so that the selection of TISOL material is tailored to the needs of adults. Second, materials in the form of assignments outside the classroom or project-based in accordance with the character of adults because this is an opportunity for adults to express themselves and express their thoughts and opinions on a topic. Third, variations in material and learning methods are needed to meet the different interests and needs of TISOL students.

Based on the description above, the role of qualified TISOL teachers is the most important requirement in realizing the success of TISOL learning. TISOL teachers are required to have a variety of competencies (professional, pedagogical, personality, and socio-cultural). For this reason, these competencies need to be presented either explicitly or implicitly in lectures or "TISOL Teacher" training.

The purpose of this study is to develop the design of the competencies of prospective TISOL teachers based on Flipped Learning. These objectives are detailed by describing the design of the competencies of prospective TISOL teachers based on Flipped Learning and describing the results of product quality in accordance with the learning needs required by TISOL students.

The next goal is the importance of applying flipped learning in Indonesian as a foreign language class. The Flipped Learning Model was chosen with the consideration that the model can optimize the learning process which certainly has an impact on good learning outcomes. The concept of Flipped Learning and its characteristics and how it is implemented in learning Indonesian as a foreign language is explained in detail and adjusted to the learning objectives to be achieved.

The objective of this research is to describe the lesson plan for understanding intercultural competence as TISOL Teachers based on Flipped Learning.

\section{METHOD}

This research uses a descriptive qualitative research approach. Qualitative research was conducted because researchers wanted to examine phenomena that could not be quantified that were descriptive such as the process of a work step, the formula of a recipe, the notions of a diverse concept, the characteristics of an item and service, pictures, styles, procedures for a culture, physical models of an artifact and so on [2]. In addition, qualitative research as a research method based on the philosophy of post-positivism, used to examine the condition of natural objects, where researchers are key instruments, data collection techniques with triangulation, data analysis is inductive or qualitative, and qualitative research results emphasize more meaning than generalization [3]. Qualitative descriptive research aims to describe and explore existing phenomena, both natural and human engineering, which pay more attention to the characteristics, quality, interrelationships between activities [4]. In addition, 
descriptive research does not provide treatment, manipulation or alteration of the variables under study, but rather describes a condition as it is. The only treatment given is the research itself, which is done through observation, interviews, and documentation. This study was designed with a qualitative approach of the literature review type.

Data analysis in qualitative research was carried out since before entering the field, while in the field and after completion in the field. Data analysis in qualitative research is carried out at the time the data collection takes place, and after the completion of data collection after completion of data collection within a certain period [3]. At the time of the interview, researchers have done an analysis of the answers interviewed. If the answers interviewed after being analyzed were not satisfactory, then the researcher would continue again to a certain stage until data was deemed credible. In addition, the activities in qualitative data analysis are carried out interactively and take place continuously until they are finished, so that the data is saturated.

The steps taken in data analysis [5] are as follows: 1) Data Reduction as a process of selecting, focusing, paying attention, simplifying, abstracting, and transforming rough data arising from field notes, so that the data gives a clearer picture of the results of observations, interviews, and documentation; 2) Data Display (data presentation), which is a collection of information arranged gives the possibility of drawing conclusions and taking action. In qualitative research the data presentation is carried out in the form of brief descriptions, charts, tables, graphs, pictograms, and the like. Through the presentation of these data, the data is organized so that it will be more easily understood; and 3) Conclusion Drawing or Verification, the researcher makes conclusions based on data that has been processed through data reduction and display. The conclusion drawn is temporary and will change if no strong evidence is found to support the next stage of data collection. However, if the conclusions raised at an early stage are supported by valid and consistent evidence when the researcher returns to the field to collect data, the conclusions put forward are credible conclusions.

In order to obtain credible research results, an examination of the validity and validity of research data is needed. According to Sugiyono [6], the implementation of the data validity checking technique in this study was based on certain criteria. The validity of the data required inspection techniques based on a number of certain criteria. There are four criteria used, namely credibility (degree of trust), tranquility, dependability, certainty. The data validity checking technique in this study is by using triangulation. Triangulation is a technique to check the validity of data by utilizing something other than the data for checking purposes or as a comparison of the data. In this study, researchers used two types of triangulation namely source triangulation and technique triangulation.

Source triangulation is to test the credibility of the data carried out by checking the data that has been obtained through several sources. Triangulation of this resource is used by researchers to check data obtained from BIPA managers, lecturers, and BIPA students. While technical triangulation is to test the credibility of the data carried out by checking the data to the same source with different techniques. Triangulation of this technique is used by researchers after getting interview results which are then checked with the results of observation and documentation.

The subjects in this study were students participating in the Indonesian Language course for Foreign Speakers (BIPA) in the Indonesian Language and Literature Department, Faculty of Language and Art, in a certain public university in Indonesia who were taking the Even Semester Academic Year 2018/2019. The subject of this research is the main informant. As triangulation, researchers utilize BIPA managers and teachers in BIPA classes. To answer the importance of FL learning in Indonesian Language classes for Foreign Speakers, the method used is a review of scientific literature and reflection on the author's pedagogical experience in teaching in BIPA classes.

\section{RESULTS AND DISCUSSION}

To improve classroom teaching in a steady, lasting way, the teaching profession needs a knowledge base that grows and improves [7]. The data sources of this research literature are three papers relating to the topic of this paper. First, a paper written by Koh Young Hun entitled 'The Application of the Flipped Learning Method in Learning Indonesian Language in Korean Colleges' presented at the International Symposium on BIPA in Jogjakarta [8]. Second, the paper titled 'Methodology of Flipped Classroom as a Learning Technology in Foreign Language Teaching', written by Kamo Chilingaryan \& Ekaterina Zvareva at the $7^{\text {th }}$ International Conference on Intercultural Education [9]. Third, a paper by Arina Evseeva \& Anton Solozhenko entitled 'Use of Flipped Classroom Technology in Language Learning' presented at the XV International Conference 'Linguistic and Cultural Studies: Traditions and Innovations [10].

The results of the literature study are then processed and analyzed according to the learning needs of TISOL students and Indonesian language proficiency standards that are good and right. Furthermore, the preparation of a learning plan based on Flipped Learning is carried out. In preparing the Flipped Learning model, it is important to consider the conditions and learning characteristics of prospective TISOL instructors and make it happen in the form of a variation of learning simulations using synchronous and asynchronous meeting models.

The learning plan results from the study and initial data analysis are as follows: a brief description of the BIPA course for TISOL teaching candidates is as follows: in this course, a pedagogical theoretical picture of BIPA learning is examined, the characteristics of BIPA students and instructors, SKL and BIPA syllabus, cross-cultural understanding, and the development of teaching materials, media, evaluations, plans learning, BIPA programs through class meetings, online, and field trips to produce teaching materials, media, evaluations, learning plans, BIPA programs as a basis for preparing research plans. 
Course Learning Outcomes for TISOL teaching candidates include: 1) utilizing science and technology as a tool in understanding the basic concepts of pedagogical theoretical images of BIPA learning, characteristics of students and prospective TISOL teachers, SKL and BIPA syllabi, crosscultural understanding, and development of teaching materials, media, evaluations, lesson plans, BIPA programs; 2) mastering BIPA learning characteristics and being able to apply them in preparing BIPA research plans; and 3) making strategic decisions in using, analyzing or studying BIPA learning. 4) taking responsibility and demonstrate ownership of the character of faith, intelligent, independent, honest, caring, and tough in completing assignments, quizzes, and tests related to pedagogical theoretical depictions of BIPA learning, characteristics of BIPA students and instructors, SKL and BIPA syllabus, cross understanding culture, and development of teaching materials, media, evaluation, learning plans, BIPA programs.

Examples of the application of variations in learning based on Flipped Learning in the BIPA course lesson plans for prospective TISOL teachers include: 1) at the second meeting, in order to achieve competence in explaining the Pedagogical Theoretic Picture of BIPA Learning, the learning simulation includes: Pre-lecture activities, students collecting material (ebooks, videos, PPT) and studying the types of BIPA learning theories (behavioral, mentalist, and interactionism). Then each student arranges three multiple choice questions and their answer keys (answer choices A-D). During the lecture, students observe, ask questions, collect, process, and communicate information about the Pedagogical Theoretical Overview of BIPA Learning using the Jigsaw Method, lecturers provide additional material, students and lecturers discuss. After that, the activities after college are online quizzes; 2) at the fourth meeting, pre-lecture activities include: Students compile presentation materials on the results of data collection on the characteristics of BIPA students and instructors. Then the activities during lectures: students observe, ask, collect, process, and communicate information about the Characteristics of BIPA Teachers, students in groups present the results of the questionnaire, students in one class do questions and answers, between groups giving an assessment of the appearance of friends. Then after the lecture, students individually compile articles (1-2 pages) about the characteristics of BIPA students and the competencies that BIPA teachers must have, and 3) for other meetings, a variety of activities are carried out before lecturing, during lectures, as well as post-lecture evaluation.

This lesson plan design is validated to experts to get suggestions, input, and criticism. Based on the results of the validation, it appears that this design is in the good category (80). The response results that are considered capable of providing positive improvement results will be a reference in implementing revisions to the lesson plans. The design of the learning plan was good, then the learning plan had seen a flipped learning model that was used as a learning model and he gave suggestions to add material for Foreign Language Teaching.

Whereas the other expert gave a good appreciation of the design of the learning plan and provided input on the activities carried out before the lecture had to be thoroughly evaluated to ensure the prospective TISOL instructors had carried out the activity properly (80). Then, the last expert opinion of TISOL teacher states that the results of the learning plan for prospective TISOL teachers are very good and can be applied. Thus, it can conclude that this design is feasible to use with a little revision that is to add more material about Foreign Language Teaching.

\section{CONCLUSION}

Researchers design Lesson Plans (RPS) and learning simulations based on Flipped Learning. Researchers as well as lecturers plan activities before in class, during class, and after class to achieve lecture competency targets. Lectures are simulated through synchronous and asynchronous activities, so that media literacy, digital literacy, and information literacy also develop. The data analysis and processing model uses the principles of data reduction, data presentation, and conclusions and verification. The credibility and validity of research data is evidenced by the triangulation technique. Based on the analysis of the data it can be concluded that the TISOL lesson plan design was good, then the learning plan had seen a flipped learning model that was used as a learning model and he gave suggestions to add material for Foreign Language Teaching. So, this design is feasible to use with a little revision that is to add more material about Foreign Language Teaching.

\section{REFERENCES}

[1] I. Suyitno, Pengembangan Bahan Ajar Bahasa Indonesia untuk Penutur Asing (BIPA) berdasarkan Hasil Analisis Kebutuhan Belajar. 2007.

[2] D. Satori and A. Komariah, Metodologi Penelitian Kualitatif. Bandung: Alfabeta, 2010.

[3] L.J. Moleong, Metodologi Penelitian Kualitatif. Bandung: PT. Remaja R

[4] S.N. Sukmadinata, Metode Penelitian Pendidikan. Bandung: PT. Remaja Rosdakarya, 2013.

[5] M.B. Miles and A.M. Huberman, Analisis Data Kualitatif: Buku Sumber tentang Metode-metode Baru. Jakarta: UI Press, 2009.

[6] Sugiyono, Metodologi Penelitian Pendidikan: Pendekatan Kuantitatif, Kualitatif, dan R \& D Eight Ed. Bandung: Alfabeta, 2009.

[7] J. Hiebert, R. Gallirmore, and J. Stigler, A Knowledge Base for the Teaching Profession: What would it look like and how can we get one? Educ. Res, 2002.

[8] Koh Young Hun, Application of the Flipped Learning Method in Indonesian Language Learning, 2017.

[9] K. Chilingaryan and E. Zvareva, Methodology of Flipped Classroom as a Learning Technology in Foreign Language Teaching. $7^{\text {th }}$ International Conference on Intercultural Education "Education Health and ICT for a Transcultural World," 2017.

[10] A. Evseeva and A. Solozhenko, Use of Flipped Classroom Technology in Language Learning. XV International Conference "Linguistic and Cultural Studies: Traditions and Innovations,” 2015. 